\title{
EVALUATION OF THE INITIATIVES OF THE EASTERN POLAND TOURISM BRANDS CLUSTER USING A MODIFIED COO EFFECT MODEL
}

\author{
Dorota RYSZKOWSKA ${ }^{1}$, Karolina GOŁĘBIESKA ${ }^{1}$, Czesław ADAMIAK ${ }^{2}$, \\ Anna OSTROWSKA-TRYZNO ${ }^{1}$, Jacek KLAWENDER ${ }^{1}$, Wojciech RYSZKOWSKI ${ }^{3}$ \\ ${ }^{1}$ Department of Tourism, Faculty of Tourism and Recreation, The Józef Pitsudski University of Physical Education \\ in Warsaw, Marymoncka str. 34, Warszawa, Poland \\ ${ }^{2}$ Department of Spatial Management and Tourism, Faculty of Earth Sciences Nicolaus Copernicus University, \\ Lwowska str. 1, Torun, Poland \\ ${ }^{3}$ Faculty of Physical Education, College of Physical Education and Tourism in Bialystok, Mickiewicza str. 49, \\ Bialystok, Poland \\ *E-mail: kozlowska_dorotka@wp.pl
}

\begin{abstract}
Purpose - the main goal of tourism clusters is to attract more tourists to the region and improve the quality of regional tourism products. The aim of this paper is to verify whether the initiative of the Eastern Poland Tourism Brands Cluster has contributed to the development of tourism services and products offered by local firms.
\end{abstract}

Research methodology - to achieve the goal, we described and evaluated cluster activities based on secondary sources of data and questionnaire interviews conducted with the representatives of entities involved in the cluster. We used the modified $\mathrm{COO}$ effect model to evaluate the services according to the following criteria: modernity, diversity, prestige and quality. We employed a 5-item Likert scale in our questionnaire.

Findings - the results of the analysis showed that despite the increased recognition of tourist brands and products, the cluster did not survive. This experience shows that clusters operating in the tourism industry have less chance of survival than industrial clusters.

Research limitations - main limitation of the research is the scarcity of source materials and a low number of surveys returned by cluster members. Personal meetings with respondents would add valuable information.

Practical implications - the results of research can be used as an indication for the development and maintenance of tourist cluster initiatives on the market. In recent years, more and more studies focus on the development prospects of tourism clusters.

Originality - until now, however, no study on cluster performance has employed the COO effect model or its derivatives, which makes our paper novel in this aspect.

Keywords: cluster, evaluation, tourism, brand, $\mathrm{COO}$ effect model, Eastern Poland.

JEL Classification: O17.

Conference topic: Contemporary Organizations Development Management.

\section{Introduction}

"A cluster is a geographical proximate group of interconnected companies and associated institutions in a particular field, linked by commonalities and externalities" (Porter, 1990). Companies operating in the cluster are independent they compete with each other and at the same time cooperate in some areas. The geographical concentration of cluster members creates a competitive advantage (Jackson \& Murphy, 2006; Arsezen-Otamisa \& Yuzbasioglu, 2013).

Tourism is a sector in which clusters allow for more effective use of the potential of a place or region (Alberti \& Giusti, 2012; Gardiner \& Scott, 2014). Seasonality in tourism forces business partners to take actions in order to effectively utilize the short periods of time when tourists are interested in specific products. The positive experience of tourists is dependent on natural and cultural amenities of the place, the diversity and accessibility of tourist services, their quality, and the diversification of the tourist offer.

Building competitive advantage in tourism is often enhanced by participation in various forms of business cooperation, including consortia, multilateral agreements, holding companies, strategic partnerships, etc. There are 
also increasingly popular public-private partnerships, forms of cooperation of business and science, and joint projects of local authorities with research and development institutions.

Joint activities of different private and public entities allow to reach goals in the fields of city or region development, more effective use of existing resources and the creation of innovative solutions. It is also needed to stress the social dimension of joint activities: the development of skills, growth of competences and promotion of active participation in local communities (Kachniewska, 2013).

Clusters give great opportunities to build a competitive advantage of tourism services and products offered in place or region. Cluster concept can be used as a useful platform for cooperation within public-private partnerships. Commercial entities, which are close geographically and operate in related sectors, may receive the support of various institutions (associations, trade organizations, universities, local authorities) (Capone, 2004; Novelli, Schmitz, \& Spencer, 2006; Porter, 1990, 2002; Skowronek, 2015).

Clusters take advantage of economies of scale and synergy. A large number of cooperating companies allows to gain new markets, expand offer, and accumulate the resources of all entrepreneurs. It also contributes to sustained growth and reduces the costs for cluster members (McLennan, Becken, \& Watt, 2016). Consequently, such clusters become important centers of knowledge, innovation, and smart development of companiesin regions. Local authorities often use these structures to build local competitive advantage. Creation of place branding awareness is a complex process, addressed to both residents and external entities (visitors, tourists, investors, etc.). A strong brand of a city or region usually correlates with the quantity and quality of investments, quality of citizens' life, popularity of the region among tourists, and residents' sense of community. Thanks to cooperation within tourism clusters, innovations based on the local social capital can be introduced (Martínez-Pérez, García-Villaverde, \& Elche, 2016). However, research shows that hotel and tourism companies have a low innovation rate and are little dependent on technology (GarcíaVillaverde, Elche, Martínez-Pérez, \& Ruiz-Ortega, 2017, p. 55), and the hotel industry puts greater emphasis on the quality of services in relation to the possibility of reducing their costs (Jung \& Jang, 2018).

The first tourist cluster in Poland was "Program for the development and promotion of tourist and cultural products of Beskidzka 5" in Beskidy Mountains in southeastern Poland. Cluster activities focused on the developing of common tourist products. The cooperation of the Beskidy communes was appreciated in international and national competitions for the best microregion campaign.

Previous research on Polish clusters resulted in recommendations that the cluster policy should focus on strengthening innovation and competitiveness of the economy through deeper cooperation, relations and flows of knowledge within clusters (Dzierżanowski, 2012). Despite many benefits resulting from cluster structures, recent studies of tourist clusters in Eastern Poland confirm their short lifespan (Borkowska-Niszczota, 2015a).

The activity of tourism clusters focuses around cooperation, promotion and advertising of the services offered by cluster members and the whole region on the international and domestic markets. Tourism clusters also create and develop collaboration in planning product chains. An important task of clusters is to prepare collaborative projects, apply for external financing sources, and maintain the cluster activity after the financing period ends. The aims of the cluster initiatives include the increase in the competitiveness of companies, products and services, development of brands and establishing inter-institutional relations. Compared to industrial clusters, tourism clusters less often introduce modern and innovative technologies. Success of a cluster depends on the quality of the soft infrastructure and cooperation between entities (Gorynia \& Jankowska, 2010).

Prior to deciding on undertaking cluster initiatives, the evaluation of their development possibilities is usually carried out. Research on the usefulness of establishment and operation of a cluster is carried out among residents of tourist destinations. Results of previous studies show that tourism planning should be more sensitive to residents, traditions and cultural heritage (Del Chiappa, Atzeni, \& Ghasemi, 2018; Laing \& Lewis, 2017). Studies performed for a different industry than tourism have revealed that in the opinions of potential members, cluster initiatives should: be a form of cooperation to achieve economic benefits, reduce the effects of economic downturn, bring new ideas, develop a company, help in acquiring new markets and new partners to cooperation, reduce production costs and conduct joint research (Duczmala \& Potwor, 2010).

\section{Data and methods}

The purpose of this research paper is to verify if cluster initiative Eastern Poland Tourist Brands has contributed to the development of services and products offered by entities participating in the cluster.

After a preliminary study of the activity of Eastern Poland Tourist Brands, an assumption was made that the end of financing contributed to the contraction of the cluster activity. Another assumption was that the cluster did not create specific products which would be competitive to previous ones and that the main benefits of cluster membership were those associated with the activities promoting the region and establishing inter-institutional cooperation.

In relation to the purpose of this research paper, the following exploratory questions were formulated:

1. What kind of activities were realized within the cluster?

2. Which of the cluster initiatives allowed achieving the best effects in promoting the region, developing services and products offered by cluster members? 
3. Which of the cluster activities are evaluated as the most important by the experts - cluster members?

4. Have the cluster initiatives contributed to the development of services and tourist products in the region?

The following methods and techniques were used to achieve the purpose of the study:

1. Analysis of the project documents was used to describe the cluster activity. A review of cluster activity in the years 2013-2017 includes: cluster objectives and types of firms-cluster members, forms of tourism offered by cluster members, 86 kinds of tourist attractions presented in the cluster offer, 455 activities and initiatives organized by cluster members, types of cluster activities and media activity aiming to promote the cluster. The analysis was performed using the information published on the official website of the cluster (klasterturystyczny.pl). In order to supplement the information gathered from the webpage, an interview was done in February 2019 with the member of staff engaged in cluster structures within Polish Advisory and Consulting Association in Białystok.

2. COO model (country-of-origin effect; Dinnie, 2004) was used since the 1960s mainly for evaluating material products, but it was also used in at least 19 publications regarding services (Boguszewicz-Kreft \& Magier-Łakomy, 2016, pp. 20-21). Authors of the publications adjusted the model to the needs of service research. The model was used for the evaluation of relations between a product and its origin, product brands, stereotypes on products from various countries, image and reputation of products. Studies using $\mathrm{COO}$ followed the analysis of products using other criteria (quantitative, qualitative, technological, criteria of innovation etc.). These criteria are closely linked to the strengths and weaknesses of a product and have a wide application for an array of products (Roth \& Romeo, 1992). The COO model was employed for the evaluation of various products and services, e.g. the perception of fresh meat by consumers (Hoffmann, 2000), the evaluation of education services (Boguszewicz-Kreft, 2014), banking services (Jaworski, Boguszewicz-Kreft, \& Magier-Łakomy, 2015), for brand positioning (Cristea, Capatina, \& Stoenescu, 2015), for assessment of products in various countries (Boguszewicz-Kreft, Magier-Łakomy, Sokołowska, \& Janiunaite, 2016), for evaluation of medical services (Boguszewicz-Kreft, Magier-Lakomy, \& Janiunaite, 2016), offer and services of selected tourist sites in rural areas (Kozłowska, Ryszkowski, \& Vasilchenko, 2016) and others. The cited studies show that the model criteria are useful in the evaluation of multidimensionality of both material and abstract (symbolic) products and services (Jaworski, Boguszewicz-Kreft, \& Magier-Łakomy, 2015), including tourism products, services, and organizations, including clusters.

Modified assumptions of $\mathrm{COO}$ model were used for its implementation in this research. Products and services were evaluated according to the following criteria:

- modernity (modern solutions and technologies in tourism),

- diversity (diversification of the tourist offer and its attractiveness),

- prestige (reputation, esteem and status in the tourist and hotel industry),

- quality (perceived as effectiveness, consistency and professionalism of tourist services and products).

Model with the application of experts' method was used to evaluate the effects of the cluster activity and initiatives. Active cluster members were invited to be experts in this research. The difficulty of conducting the research resulted from a low number of experts willing to engage in the study. Presumably, the negligible activity of the cluster currently could be a reason for unwillingness to take part in the research.

3. The questionnaire interview was conducted among experienced members of staff of the firms participating in the cluster. Questions for the questionnaire were designed according to the following guidelines:

- following a conceptual model of competitiveness of the regional tourist cluster (Estevão \& Ferreira, 2009); - following the model of innovative regional cluster as a model of tourism development (Fundeanu, 2015);

- on the basis of objectives of the Eastern Poland Tourist Brands Cluster.

Research results were presented in the following order:

1. Analysis of activities and initiatives of Eastern Poland Tourist Brands Cluster.

2. Evaluation of the cluster's activity based on the modified $\mathrm{COO}$ model.

\subsection{Characteristics of the expert informants}

Five experts took part in the research. They were members of the Eastern Poland Tourism Brands Cluster. Women were a minority compared to men. The respondents were in the age range between 38 and 56 years old, all held Master degrees. They run businesses mainly in cities in Podlaskie (4) and Warmińsko-Mazurskie (1) voivodships. Their professional experience in the tourism industry varied within the range between 7 and 18 years of practice, mostly in high positions (attorney, president of the board, deputy director).

Their experiences related to the cluster involved: the knowledge of the project, direct involvement in the cluster activities and membership in the cluster. Each of the respondents participated in up to a dozen events related to the implementation of the project. Cluster members mainly remember program meetings related to the implementation of the project, training conferences, but also study tours and workshops. Three experts were in favor of resuming the cluster initiative, while two did not have an opinion on the subject. The respondents indicated that in the implementation of the project, it would be possible to improve the joint promotion of cluster members in a continuous manner. As the main effects achieved in the cluster, the respondents considered the participation in study tours, promotion, new knowledge and skills of cooperation, and raising for funds for development (see Table 1). 
Ryszkowska, D.; Gotębieska, K.; Adamiak, C.; Ostrowska-Tryzno, A.; Klawender, J.; Ryszkowski, W. 2019. Evaluation of the initiatives of the eastern Poland tourism brands cluster using a modified coo effect model

Table 1. Characteristics of the subjects (source: own elaboration)

\begin{tabular}{|c|c|c|c|}
\hline Sex & $\mathrm{N}$ & Knowledge related to partnership and membership in the cluster & $\mathrm{N}$ \\
\hline Female (F) & 2 & I have knowledge related to partnership in the cluster & 4 \\
\hline Male (M) & 3 & I am a direct, active (involved) participant in the cluster & 3 \\
\hline \multicolumn{2}{|l|}{ Age } & I have been/was a cluster member for some time & 2 \\
\hline 38 & 1 & \multicolumn{2}{|l|}{ Participation in events related to the implementation of the project } \\
\hline 42 & 1 & Once & 1 \\
\hline 47 & 1 & Three times & 1 \\
\hline 50 & 1 & Five years & 1 \\
\hline 56 & 1 & Several times & 1 \\
\hline \multicolumn{2}{|l|}{ Education } & Dozen times & 1 \\
\hline Bachelor degree & 0 & Events that are most memorable to the cluster member & \\
\hline Master degree & 5 & Program-project meetings & 3 \\
\hline \multicolumn{2}{|l|}{ Place of business } & Training conferences & 3 \\
\hline city & 4 & Other: study tours & 2 \\
\hline Rural area & 1 & Workshops & 1 \\
\hline \multicolumn{2}{|c|}{$\begin{array}{l}\text { Location of cluster member's business } \\
\text { (voivodeship) }\end{array}$} & \multicolumn{2}{|l|}{ Opinion about the willingness to resume the cluster's initiative } \\
\hline $\begin{array}{l}\text { Podlaskie: Augustów, Białystok, } \\
\text { Szepietowo }\end{array}$ & 4 & Definitely yes & 3 \\
\hline Warmińsko-Mazurskie & 1 & No opinion & 2 \\
\hline Position & & \multicolumn{2}{|c|}{$\begin{array}{l}\text { Barriers and issues that could be improved in the activities/initiatives of the } \\
\text { cluster }\end{array}$} \\
\hline Attorney & 1 & \multicolumn{2}{|c|}{ Joint promotion carried out on a continuous basis } \\
\hline President of the board & 1 & \multicolumn{2}{|l|}{ The main effects achieved in the Eastern Poland Tourism Brands Cluster } \\
\hline Deputy director & 1 & \multirow{2}{*}{\multicolumn{2}{|c|}{$\begin{array}{l}\text { Participation in study tours, promotional activities, gaining knowledge and } \\
\text { skills in the field of cooperation, raising funds for development }\end{array}$}} \\
\hline No answer & 2 & & \\
\hline \multicolumn{4}{|c|}{ Professional experience (years) in the industry related to the implementation of the cluster's goals (tourism/hotel/other related) } \\
\hline \multicolumn{2}{|c|}{ Measure } & \multicolumn{2}{|c|}{ Value } \\
\hline \multicolumn{2}{|l|}{ Count } & \multicolumn{2}{|l|}{5} \\
\hline \multicolumn{2}{|l|}{ Sum } & \multicolumn{2}{|l|}{51} \\
\hline \multicolumn{2}{|l|}{ Standard deviation } & \multicolumn{2}{|l|}{4,02} \\
\hline \multicolumn{2}{|l|}{ Mean } & \multicolumn{2}{|l|}{10,2} \\
\hline \multicolumn{2}{|l|}{ Minimum } & \multicolumn{2}{|l|}{7} \\
\hline \multicolumn{2}{|l|}{ Median } & \multicolumn{2}{|l|}{8} \\
\hline \multicolumn{2}{|l|}{ Maximum } & \multicolumn{2}{|l|}{18} \\
\hline
\end{tabular}

\section{Results}

\subsection{Analysis of activities and initiatives of the Eastern Poland Tourism Brands Cluster}

\subsubsection{Members and aims of the cluster}

At the end of 2013, the Polish Advisory and Consulting Association performed a study in order to prepare the marketing strategy of Eastern Poland Tourism Brands Cluster. They used a quantitative survey using the CATI technique among 500 randomly selected respondents - inhabitants of Podlaskie and Warmińsko-Mazurskie Voivodeships, which is the area of activity of the cluster. The results have shown that, as tourists, the respondents would be attracted by a touristic offer for customers with diverse financial and family situations, information activities, and modernization of road infrastructure. $46 \%$ of respondents were interested in nature-based tourism. $34 \%$ pointed at rural tourism, sightseeing and spa tourism, $32 \%$ indicated active forms of spending time. $42 \%$ of respondents claimed that the prices of services are too high, $39 \%$ described the road infrastructure as deficient, $36 \%$ pointed at an insufficient information about the attractions of the region. The respondents also mentioned insufficient number of free parking lots and a small number of rail and bus connections.

Eastern Poland Tourism Brands Cluster was established in 2011 and its financing was implemented from the Operational Program Eastern Poland 2007-2013, within the task "promotion and cooperation". The area of activities 
is Podlaskie and Warmińsko-Mazurskie Voivodships. The value of the project was estimated at PLN 3915800.00 , including the financial aid of PLN 2995 587.00. The project was designed and led by the Polish Advisory and Consulting Association. The cluster had the following goals:

- building awareness of the Cluster's importance on the regional, national and global market;

- improvement of the Cluster's innovativeness and competitiveness by adopting recommendations stemming from the research performed;

- development of activities aimed at promoting the offer of cluster members through the organization of seminars, conferences and study tours;

- promotions of area brands in order to increase their visibility;

- offering the highest quality services;

- care for the positive image of the Cluster and its participants;

- applying for funds from external financing sources (Polskie Stowarzyszenie Doradcze I Konsultingowe, 2013; www.polskawschodnia.2001-2013.gov.pl).

The effects that the cluster was supposed to bring for the participating entities were oriented on the growth of innovation, competitiveness, increase in turnover, number of customers and employment, and reduction of marketing costs. The cluster's interest was focused on: various types of tourism services and tourism products; accommodation and catering facilities, tourism market research, professional trainings and workshops, organization of conferences, fairs and foreign study tours; support of product sales and participation in the implementation of tourism development strategies at the level of local and voivodeship administration (PSDiK, 2013). Based on the analysis of the cluster's website (klasterturystyczny.pl), there were 39 members of the cluster from Podlaskie and Warmińsko-Mazurskie Voivodships, related to various types of economic activity. Among the cluster members, hotel activity prevailed (see Figure 1).

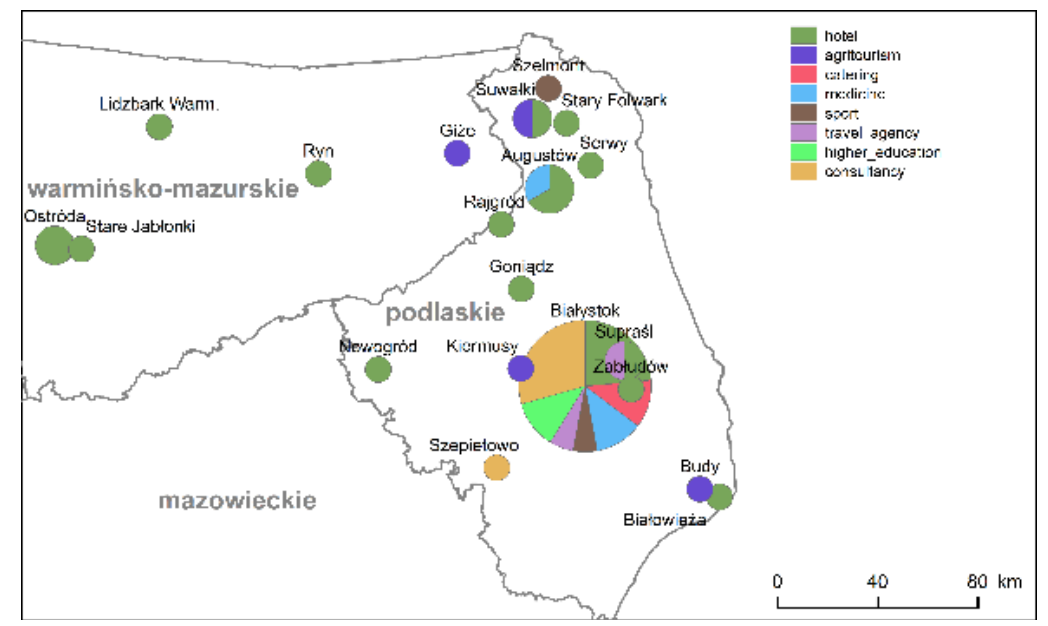

Figure 1. Location of members of Eastern Poland Tourism Brands Cluster (source: own elaboration)

\subsubsection{Types of tourism offer of cluster members}

Cluster members have a wide offer addressed to clients-tourists. In principle, all members offered leisure tourism services. Almost 3/4 members had an offer for the business, and 61.54\% offered specific services for business tourism. Fewer members offered services related to health tourism, wellness and SPA. Slightly over $1 / 4$ of cluster members invited for weekend tourism. Much fewer objects directed their offer to families and tourists engaged in active tourism, although the location of most cluster members favours such forms of tourism. Historical tourism and educational offer for schools were found in the case of $10-20 \%$ of cluster members. There were also few offers of services provided by foundations, other organizations and travel agencies (see Table 2).

Table 2. Types of tourism offer of cluster members (source: own study based on klasterturystyczny.pl)

\begin{tabular}{|l|c|c|}
\hline \multicolumn{1}{|c|}{ Offer } & Number of objects offering services & $\%$ \\
\hline Leisure tourism & 39 & $100.00 \%$ \\
\hline Offer for business & 28 & $71.79 \%$ \\
\hline Business tourism & 24 & $61.54 \%$ \\
\hline Health. spa and wellness & 23 & $58.97 \%$ \\
\hline Weekend tourism & 11 & $28.21 \%$ \\
\hline
\end{tabular}


Ryszkowska, D.; Golębieska, K.; Adamiak, C.; Ostrowska-Tryzno, A.; Klawender, J.; Ryszkowski, W. 2019. Evaluation of the initiatives of the eastern Poland tourism brands cluster using a modified coo effect model

End of Table 2

\begin{tabular}{|l|c|c|}
\hline \multicolumn{1}{|c|}{ Offer } & Number of objects offering services & $\%$ \\
\hline Family tourism & 7 & $17.95 \%$ \\
\hline Active tourism & 7 & $17.95 \%$ \\
\hline Historical tourism & 6 & $15.38 \%$ \\
\hline For schools & 5 & $12.82 \%$ \\
\hline By foundations. organizations & 4 & $10.26 \%$ \\
\hline Travel agency services & 1 & $2.56 \%$ \\
\hline
\end{tabular}

\subsubsection{Tourist attractions of the region presented in the cluster's offer}

The analysis showed that the Eastern Poland Tourism Brands Cluster advertised in its materials 86 tourist attractions located near the members of the cluster. Most cluster members were located near the Summer Residence of the Branicki family in Choroszcz - the current Museumof Palace Interiors. A similar number of cluster members was located near attractions located in or near Bialystok, the capital city of Podlaskie voivodeship, and close to nature-rich areas: national parks and stork village. Almost $1 / 4$ of the cluster members were located near the historical town of Tykocin. Significantly fewer cluster members were located in the Natura 2000 area, in the North and South of Suwałki region. Few cluster members were located near tourist attractions located mainly Masuria and Warmia, as well as among some attractions of Podlasie (see Table 3).

Table 3. Tourist sites located near cluster members (source: own study based on klasterturystyczny.pl)

\begin{tabular}{|c|c|c|}
\hline In total 86 objects & $\begin{array}{c}\text { Number of } \\
\text { clustermembers }\end{array}$ & $\%$ \\
\hline Letnia rezydencja Branickich w Choroszczy & 14 & $16.28 \%$ \\
\hline $\begin{array}{l}\text { Kraina Otwartych Okiennic; Kościół św. Rocha w Białymstoku; Pałac i Ogród Branickich w } \\
\text { Białymstoku; Białostockie Muzeum Wsi; Puszcza Knyszyńska; Szlakiem esperanto; Szlakiem } \\
\text { białostockich fabrykantów; Szlakiem rodu Branickich; Białystok wielokulturowy. Szlakiem świątyń.; } \\
\text { Szlakiem architektury drewnianej; Kościół Trójcy Przenajświętszej w Tykocinie; Muzeum Ikon w } \\
\text { Supraślu }\end{array}$ & 13 & $15.12 \%$ \\
\hline Narwiański Park Narodowy & 12 & $13.95 \%$ \\
\hline Europejska WieśBociana - Pentowo & 11 & $12.79 \%$ \\
\hline Tykocin; Synagoga i Dom Talmudyczny w Tykocinie; Zamek w Tykocinie & 10 & $11.63 \%$ \\
\hline Ruiny pałacu Paca & 9 & $10.47 \%$ \\
\hline Dolina Rospudy; Uroczysko Święte Miejsce & 8 & $9.30 \%$ \\
\hline $\begin{array}{l}\text { Muzeum Wigier; Wigierski Park Narodowy; Klasztor kamedułów w Wigrach; Wigierska Kolej } \\
\text { Wąskotorowa; Kanał Augustowski; Czarna Hańcza; Augustów; Żegluga Augustowska }\end{array}$ & 7 & $8.14 \%$ \\
\hline Studzieniczna & 6 & $6.98 \%$ \\
\hline Puszcza Augustowska & 5 & $5.81 \%$ \\
\hline Świątynia w Krasnymborze; Cmentarzysko w Szwajcarii; Festyn Jaćwieski Szwajcaria & 4 & $4.65 \%$ \\
\hline $\begin{array}{l}\text { Giby; Wyciąg nart wodnych i tor kajakowy w Ostródzie; Zamek w Ostródzie; Molo ze skocznią w } \\
\text { Olecku; Osada Jaćwiesko-Pruska; Suwalski Park Krajobrazowy; Góra Zamkowa w Szurpiłach; Jezioro } \\
\text { Hańcza; Wiewiórcza ścieżka w Olecku }\end{array}$ & 3 & $3.49 \%$ \\
\hline $\begin{array}{l}\text { Święto Ziemniaka w Mońkach; Obszar Ochrony Ścisłej Puszczy Białowieskiej; Muzeum Przyrodniczo- } \\
\text { Leśne w Białowieży; Park Pałacowy w Białowieży; Rezerwat Pokazowy Żubrów w Białowieży; Ełcka } \\
\text { Kolej Wąskotorowa; Zamek Krzyżacki w Ełku; Trójstyk granic w Bolciach; Twierdza Osowiec; Muzeum } \\
\text { Lipskiej Pisanki i Tradycji; Biebrzański Park Narodowy }\end{array}$ & 2 & $2.33 \%$ \\
\hline $\begin{array}{l}\text { Dni Truskawki w Korycinie; Szlak księdza Jerzego Popiełuszki; Silvarium Nadleśnictwa Krynki w } \\
\text { Poczopku; Zamek Krzyżacki w Rynie; Słup graniczny w Prostkach; Głaz w Starych Juchach; Bezkrwawe } \\
\text { Safari; Wieża widokowa w Starych Juchach; Puszcza Romincka; Twierdza Boyen w Giżycku; Mosty w } \\
\text { Stańczykach; Puszcza Borecka; Kurpiowska Puszcza Zielona; Skansen kurpiowski w Nowogrodzie; } \\
\text { Sanktuarium w Świętej Lipce; Głazowisko Fuledzki Róg; Wilczy Szaniec w Gierłoży; "Amfiteatr" w } \\
\text { Rynie; Wieś tatarska Bohoniki; Hodowla tarpanów w Popielnie; Góra Czterech Wiatrów; Rezerwat } \\
\text { przyrody Borki; Tatarska Góra; Park Dzikich Zwierząt w Kadzidłowie }\end{array}$ & 1 & $1.16 \%$ \\
\hline $\begin{array}{l}\text { Dwór Klewiny; Święta Góra Grabarka; Piramida w Rapie; Grobowiec w Zakałczu Wielkim; Głazy } \\
\text { Wilhelma II; Republika Ściborska; Wieś tatarska Kruszyniany; Piękna Góra }\end{array}$ & 0 & - \\
\hline
\end{tabular}


It can be noticed that the list of attractions placed on the cluster's website is very limited in comparison to the actual number of tourist attractions of the discussed area. This may result from a lack of general knowledge on tourism resources of the area, as well as of a lack of knowledge about newly established objects. It can be presumed that the cluster's goals were focused on promoting the region and clusters in a different form than preparing a guide about tourist attractions. Figure 2 presents the types of tourist attractions in the discussed area described on the cluster website.

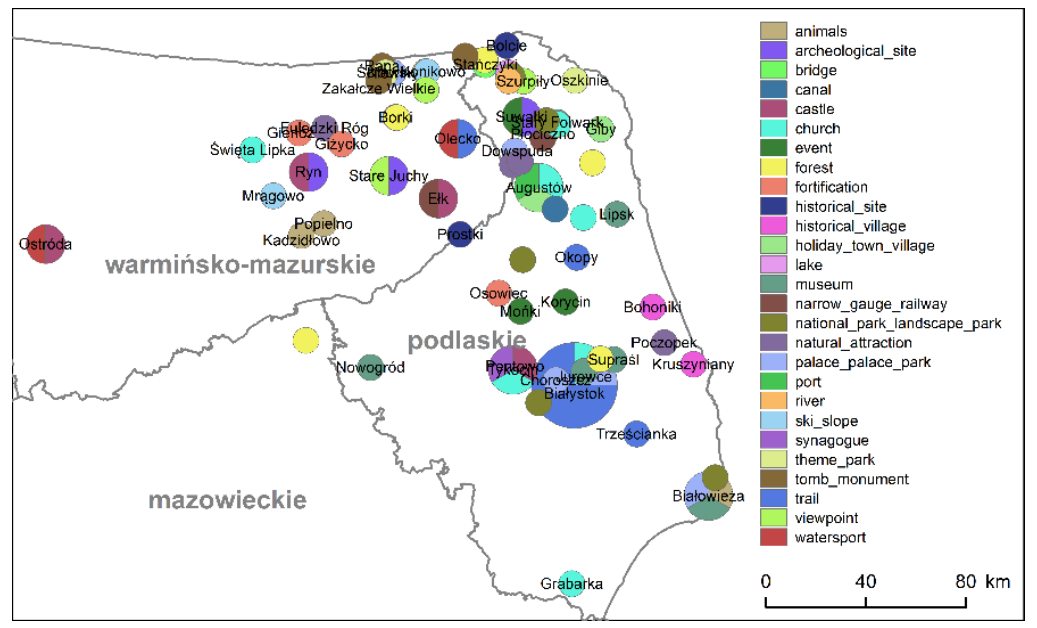

Figure 2. Types of tourist attractions located near the cluster members (source: own elaboration)

\subsubsection{Overview of the activities of the Eastern Poland Tourism Brands Cluster in the years 2013-2017}

An analysis of 455 events posted in the cluster's activity news webpage showed that more than half of the cluster's information was related to tourist packages offered in their facilities. Most often there were packages related to religious holidays and special events like Valentine's Day, New Year's Eve, St. Andrew's Day, etc., and an offer related to business meetings (events, conferences and meetings). Cluster members invited to workshops and fairs organized at their premises. Dworek nad Łąkami in Kiermusy published the largest number of information about the fairs. In this object, the fairs of "antiques, crafts and handicrafts" have been a tradition for many years. Cluster members took part in external competitions for the quality of services offered and won prizes and awards in various categories. They received them, among others, for catering, and the quality of service in the facility. The Suwalki Chamber of Agriculture and Tourism was the only one offering a network product and received many awards for this product (network product was implemented based on another EU project). Cluster members participated in various conferences and national and outbound study tours related to the implementation of the project. The most important foreign visits were those to the United States, China and Russia. The remaining ones were trips to neighbouring countries, such as Lithuania, Belarus, etc. Some study and conference trips were realised by cluster members within other projects. In these countries, cluster members promoted their own tourist facilities and presented the attractiveness of the NorthEastern region of Poland. Other conferences, trainings and seminars were also organized by non-cluster institutions, but they were important for cluster members' business activity and helpful in the introduction of modern solutions.

Table 4. Organization and/or participation of cluster members in tourism events in 2013-2017 (source: own elaboration)

\begin{tabular}{|l|c|c|c|c|c|c|c|c|c|c|c|c|}
\hline $\begin{array}{c}\text { Organization / participation } \\
\text { in event }\end{array}$ & 2013 & $\%$ & 2014 & $\%$ & 2015 & $\%$ & 2016 & $\%$ & 2017 & $\%$ & Total & $\%$ \\
\hline Offer of tourist packages & 33 & $7.25 \%$ & 150 & $32.97 \%$ & 69 & $15.16 \%$ & 9 & $1.98 \%$ & 7 & $1.54 \%$ & 268 & $58.90 \%$ \\
\hline Workshops, fairs, events & 4 & $0.88 \%$ & 29 & $6.37 \%$ & 9 & $1.98 \%$ & 4 & $0.88 \%$ & 8 & $1.76 \%$ & 54 & $11.87 \%$ \\
\hline Participation in competitions & 0 & - & 21 & $4.62 \%$ & 5 & $1.10 \%$ & 5 & $1.10 \%$ & 3 & $0.66 \%$ & 34 & $7.47 \%$ \\
\hline $\begin{array}{l}\text { Conferences related to the } \\
\text { project }\end{array}$ & 3 & $0.66 \%$ & 12 & $2.64 \%$ & 5 & $1.10 \%$ & 2 & $0.44 \%$ & 0 & - & 23 & $5.05 \%$ \\
\hline $\begin{array}{l}\text { Other conferences, trainings, } \\
\text { seminars }\end{array}$ & 1 & $0.22 \%$ & 13 & $2.86 \%$ & 2 & $0.44 \%$ & 4 & $0.88 \%$ & 0 & - & 20 & $4.40 \%$ \\
\hline Sport events & 0 & - & 7 & $1.54 \%$ & 5 & $1.10 \%$ & 3 & $0.66 \%$ & 0 & - & 15 & $3.30 \%$ \\
\hline Meetings with interesting people & 2 & $0.44 \%$ & 11 & $2.42 \%$ & 2 & $0.44 \%$ & 0 & - & 0 & - & 15 & $3.30 \%$ \\
\hline Participation in fairs & 0 & - & 6 & $1.32 \%$ & 4 & $0.88 \%$ & 1 & $0.22 \%$ & 3 & $0.66 \%$ & 13 & $2.86 \%$ \\
\hline Other events & 0 & - & 13 & $2.86 \%$ & 0 & - & 0 & - & 0 & - & 13 & $2.86 \%$ \\
\hline Total & 43 & $9.45 \%$ & 262 & $57.58 \%$ & 101 & $22.20 \%$ & 28 & $6.15 \%$ & 21 & $4.62 \%$ & 455 & 100 \\
\hline
\end{tabular}


Cluster members, whose location, resources and offer allowed for the organization of sports events, posted information on ski events, competitions and other events. Here, in particular, the Provincial Sports and Recreation Center was promoted at Lake Szelment on Jesionowa Góra. There were also prestigious meetings with TV stars of programs devoted to cooking, with business people and other meetings with interesting people, and vernissages. Cluster members participated in domestic and foreign fairs promoting the region and tourist facilities with the use of promotional materials produced for the cluster. Information materials featured also announcements of other events, e.g. Białystok University of Technology published information about recruitment for studies. The analysis showed that almost $3 / 4$ of the events took place in 2014-2015, i.e. during the period of rapid development and financing of the cluster project (see Table 4).

\subsubsection{Activities of cluster members}

Based on the cluster activity an observation can be made that the number of tourist attractions localized nearby the tourist/hotel facility of the cluster member did not have any impact on the number of tourist packages or other services offered by the facility. Only selected tourist attractions around the cluster members' area were used in the implementation of the project and the selection was probably driven by intuition. Incomplete knowledge about cultural and natural attractions in the area hampered their efficient use.

Most of the operations were realized by governmental and non-governmental organizations unrelated to the cluster, e.g. contests were mostly organized by external private and governmental institutions. The same applies to workshops and other events, as well as participation in domestic and international trade shows that bring together various exhibitors and cluster members.

The most active members of the clusterwere hotel and leisure businesses. They are members of the Anders Group from Warmian-Masurian Voivodeship. In Podlaskie Voivodeship these included: Manor above Meadows in Kiermusy located near Białystok, "Warsaw" hotel from Augustów (Sudovia) and "Żubrówka" hotel located within Białowieża Forest. Other active members of the cluster included: university in Białystok, sporting and recreational organization WOSiR, Sudovian Chamber of Agriculture and Tourism (SIRT) and Podlaskie Agricultural Advisory Centre (PODR). Almost a quarter of cluster members were not active in promoting their facilities on the website (excluding the partnership "W sercunatury" which hosted a website and was a member of the cluster (see Table 5).

Table 5. Activities of cluster members in the years 2013-2017 (source: own elaboration)

\begin{tabular}{|c|c|c|c|c|c|c|c|c|c|c|c|}
\hline Name of the cluster member & 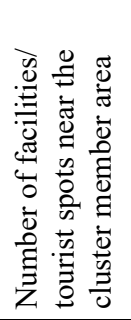 & 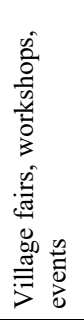 & 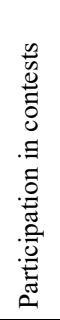 & 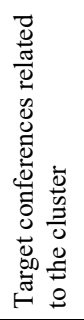 & 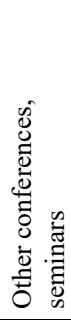 & 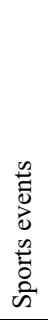 & 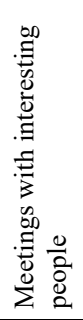 & 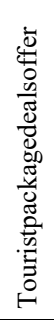 & 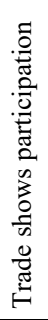 & 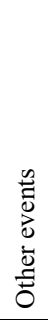 & 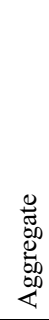 \\
\hline Other & - & 15 & 21 & 8 & 4 & 1 & 1 & 4 & 9 & 3 & 66 \\
\hline Anders Group: Krasicki Hotel & 18 & 1 & 2 & - & 1 & & 4 & 22 & - & & 30 \\
\hline Anders Group: Anders Hotel & 17 & - & 2 & - & - & 4 & - & 24 & - & & 30 \\
\hline Manor above Meadows in Kiermusy & 10 & 15 & - & - & 1 & - & - & 11 & - & & 27 \\
\hline Anders Group: Ryn Castle & 17 & 2 & 1 & - & - & - & - & 23 & - & & 26 \\
\hline "Warsaw SPA \& RESORT" Hotel & 14 & - & - & - & - & - & - & 23 & - & & 23 \\
\hline Żubrówka Hotel ${ }^{* * * *}$ & 10 & 1 & - & - & - & - & - & 22 & - & & 23 \\
\hline $\begin{array}{l}\text { Condohotels Group: Willa Port Conference } \\
\text { Resort \& SPA Hotel }\end{array}$ & 15 & - & - & - & - & 1 & 1 & 20 & - & & 22 \\
\hline $\begin{array}{l}\text { Białystok University of Technology/Faculty } \\
\text { of Management }\end{array}$ & - & 4 & 2 & 2 & 3 & 1 & - & - & - & 8 & 20 \\
\hline $\begin{array}{l}\text { Sudovian Chamber of Agriculture and } \\
\text { Tourism (SIRT) }\end{array}$ & - & 5 & 1 & 2 & 1 & - & - & 8 & - & & 17 \\
\hline WOSiRSzelment & - & - & - & - & - & 8 & 2 & 7 & - & & 17 \\
\hline Podlaskie Agricultural Advisory Centre & 2 & 2 & 3 & 1 & 5 & - & 1 & - & 4 & & 16 \\
\hline Szyszko Hotel & 11 & - & - & - & - & - & - & 15 & - & & 15 \\
\hline $\begin{array}{l}\text { University of Finance and Management in } \\
\text { Białystok }\end{array}$ & - & 1 & - & 4 & 3 & - & 5 & - & - & 1 & 14 \\
\hline Gołębiewski Hotel in Białystok & 14 & 4 & - & - & - & - & - & 9 & - & & 13 \\
\hline
\end{tabular}


Ryszkowska, D.; Gotębieska, K.; Adamiak, C.; Ostrowska-Tryzno, A.; Klawender, J.; Ryszkowski, W. 2019. Evaluation of the initiatives of the eastern Poland tourism brands cluster using a modified coo effect model

End of Table 5

\begin{tabular}{|c|c|c|c|c|c|c|c|c|c|c|c|}
\hline Name of the cluster member & 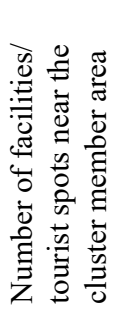 & 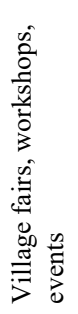 & 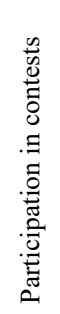 & 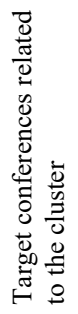 & 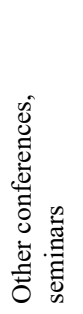 & 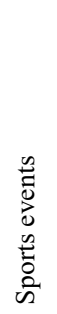 & 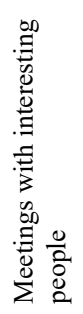 & 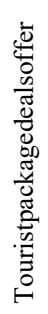 & 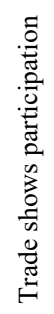 & 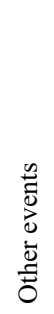 & 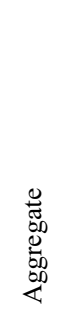 \\
\hline $\begin{array}{l}\text { Condohotels Group: Platinum Aqua Fun \& } \\
\text { Events Hotel }\end{array}$ & 15 & - & - & - & - & - & - & 12 & - & & 12 \\
\hline Albatros Hotel & 14 & - & - & - & - & - & - & 12 & - & & 12 \\
\hline Zbyszko Hotel in Nowogród & 10 & - & - & - & - & - & - & 8 & - & & 8 \\
\hline Best Western CRISTAL Hotel $* * *$ & 24 & - & - & - & - & - & - & 7 & - & - & 7 \\
\hline $\begin{array}{l}\text { BorowinowyZdrój Wellness SPA \& } \\
\text { Conference Hotel }\end{array}$ & 18 & - & - & - & - & - & - & 7 & - & - & 7 \\
\hline Podlasie Hotel & 13 & - & - & - & 1 & - & 1 & 5 & - & & 7 \\
\hline Polish Advisory and Consulting Association & - & 1 & - & 6 & - & - & - & - & - & - & 7 \\
\hline Gościnna Kamienica & 18 & - & - & - & - & - & - & 6 & - & - & 6 \\
\hline Sioło Budy & 1 & - & 1 & - & - & - & - & 5 & - & & 6 \\
\hline Health Resort \& Sanatorium in Augustów & 2 & - & - & - & - & - & - & 5 & - & & 5 \\
\hline Agritourist Association "Masurian Land" & 1 & 2 & 1 & - & 1 & - & - & 1 & - & & 5 \\
\hline Beaver Valley & 18 & - & - & - & - & - & - & 4 & - & - & 4 \\
\hline Augustów Hostel & 14 & - & - & - & - & - & - & 4 & - & & 4 \\
\hline Energetyk Rajgród & 18 & - & - & - & - & - & - & 2 & - & - & 2 \\
\hline $\begin{array}{l}\text { Titanic Conferencing and Banqueting } \\
\text { Centre }\end{array}$ & - & - & - & - & - & - & - & 1 & - & - & 1 \\
\hline Holiday - Gastronomy, Accommodation & 14 & - & - & - & - & - & - & 1 & - & & 1 \\
\hline $\begin{array}{l}\text { Podlaskie Fondation of Sports, Tourism and } \\
\text { Environment SWT }\end{array}$ & 4 & 1 & - & - & - & - & - & - & - & & 1 \\
\hline Amicus Society & - & - & - & - & - & - & - & - & - & 1 & 1 \\
\hline "BIAL-TUR" Travel Agency & 23 & - & - & - & - & - & - & - & - & - & 0 \\
\hline Eurofirma Media Sp. z o.o. & 18 & - & - & - & - & - & - & - & - & - & 0 \\
\hline The Green Lungs of Poland Foundation & 18 & - & - & - & - & - & - & - & - & - & 0 \\
\hline Gastro Strefa S.C & 18 & - & - & - & - & - & - & - & - & - & 0 \\
\hline $\begin{array}{l}\text { NOVILINE Surgery and Aesthetic } \\
\text { Medicine Clinic M. Nowicka }\end{array}$ & 8 & - & - & - & - & - & - & - & - & & 0 \\
\hline Zbyszko Center in Goniądz*** & 5 & - & - & - & - & - & - & - & - & & 0 \\
\hline REVIT Sp. z o.o. & 2 & - & - & - & - & - & - & - & - & & 0 \\
\hline Sports \& Recreation Association "Golfstok" & - & - & - & - & - & - & - & - & - & & 0 \\
\hline W Sercu Natury Sp. z o.o. & - & - & - & - & - & - & - & - & - & & 0 \\
\hline \multicolumn{2}{|l|}{ Total } & 268 & 54 & 34 & 23 & 20 & 15 & 15 & 13 & 13 & 455 \\
\hline
\end{tabular}

\subsubsection{Media activity for the promotion of the region and the Eastern Poland Tourist Brands}

Cluster Media information regarding the activity of the cluster were mainly short interviews published in the local and regional branch press. Advertising campaign "In the Heart of Nature - Podlaskie, Sudoviaand Masuria" included radio and TV spots, Internet promotion, press reports and short TV coverage's from the meetings. Media information presented international study tours as well as awards for the best cluster members. Information about the Congress of Polish Clusters in the Parliament and the existence of automotive route in Podlaskie Voivodeship also appeared in media.

Furthermore, folders, flyers and other informational, promotional and marketing materials were prepared in Polish, English and Russian language to present cluster members' offer. 


\section{Evaluation of cluster activity based on modified COO method -results of a survey on expert opinion}

\subsection{Category of quality}

In the category of quality 3 experts agreed that cluster membership improved and facilitated contacts with institutions offering similar products. They were also rather sure that the membership brought a more thoughtful approach to innovation and modernity.

Divergence in experts' opinions occurred when evaluating: conducting research, improving company management, improving the quality of the products and services, and functioning among clients using their products and services. The cooperation between academic sector and business was unnoticeable in the opinion of two experts, while other next experts rated it positively (see Table 6).

Table 6. Evaluation of cluster activity based on modified COO estimation according to quality criterion in experts' opinion (source: own elaboration)

\begin{tabular}{|c|c|c|c|c|c|}
\hline \multirow[b]{2}{*}{ Quality criterion } & \multicolumn{5}{|c|}{ Level } \\
\hline & 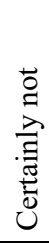 & 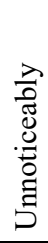 & 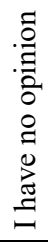 & 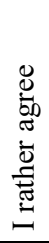 & 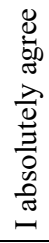 \\
\hline $\begin{array}{l}\text { Facilitation and improvement of contacts between institutions offering } \\
\text { similar products to these of the firm-member of the cluster }\end{array}$ & 0 & 1 & 1 & 1 & 3 \\
\hline $\begin{array}{l}\text { Thoughtful approach to innovations / modernity realized in cluster and } \\
\text { own company }\end{array}$ & 0 & 1 & 1 & 3 & 0 \\
\hline $\begin{array}{l}\text { Conducting research associated with the competitiveness of the product / } \\
\text { services / development of the region }\end{array}$ & 0 & 2 & 1 & 2 & 0 \\
\hline Company organization and management improvement & 0 & 2 & 1 & 2 & 0 \\
\hline Improvement of products / services quality & 0 & 2 & 1 & 2 & 0 \\
\hline Close cooperation of business and education sectors & 0 & 2 & 1 & 2 & 0 \\
\hline $\begin{array}{l}\text { Functioning in concentrations comprising not only cluster companies } \\
\text { but also their clients and users of their products/services }\end{array}$ & 0 & 2 & 1 & 2 & 0 \\
\hline
\end{tabular}

\subsection{Category of diversity}

Experts (3) definitely agreed that cluster membership fostered the establishment of a relation between cluster members and helped to acquire knowledge of innovations through study tours. Fewer experts noticed easier access to customer and additional knowledge due to training courses and workshops participation. Three experts rather agreed that the cluster activities helped to inform better about products and services of the company. Some experts were rather certain that cluster activities helped in acquiring new customers, interacting with companies from outside of the cluster, and cooperation in the working on the strategy of tourism development on the level of local and voivodeship authorities.

Divergence in experts' opinions appeared in evaluating the effects of expansion, marketing and promotion support from the cluster on the sales of own products and services.

Introducing new technologies in own company, financing investments from EU funds due to cluster partnership and access to free trainings and workshops were evaluated rather negative by experts, or experts had no opinion on these aspects of cluster activity. Possibly, not all cluster members were properly informed about training offer, or they did not want to benefit from further education, hence the opinions could be divergent (see Table 7).

\subsection{Category of prestige}

In case of the prestige category, there were serious divergences in all the evaluations. Most of the experts agreed that the cluster contributed to the organization and participation in trade shows, strengthened the brand of the region and cluster members' prestige, and promoted the whole region, as well as individual cluster members on domestic and foreign markets.

Large divergence in opinions concerned incorporating tourism into the regional development strategy, encouraging cluster members to introduce innovations, and intensification of promotion. 
Ryszkowska, D.; Gołęieska, K.; Adamiak, C.; Ostrowska-Tryzno, A.; Klawender, J.; Ryszkowski, W. 2019. Evaluation of the initiatives of the eastern Poland tourism brands cluster using a modified coo effect model

Table 7. Evaluation of cluster activity based on modified COO estimation according to criterion of diversity in experts' opinion (source: own elaboration)

\begin{tabular}{|c|c|c|c|c|c|}
\hline \multirow[b]{2}{*}{ Diversity criterion } & \multicolumn{5}{|c|}{ Level } \\
\hline & 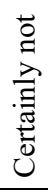 & 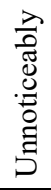 & 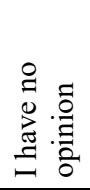 & 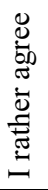 & 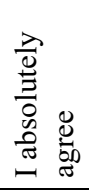 \\
\hline Inter-institutional relations establishment in the cluster & 0 & 1 & 0 & 1 & 3 \\
\hline Usage of study tours in order to acquire knowledge of innovations in tourism & 0 & 1 & 1 & 0 & 3 \\
\hline Facilitated knowledge acquisition & 0 & 1 & 1 & 1 & 2 \\
\hline $\begin{array}{l}\text { Access to new and supplemental knowledge through participation in training } \\
\text { courses/workshops realized within the cluster }\end{array}$ & 0 & 1 & 1 & 1 & 2 \\
\hline Better information about products/services in the company & 0 & 1 & 1 & 3 & 0 \\
\hline Acquiring new customers & 0 & 1 & 1 & 3 & 0 \\
\hline Establishing cooperation with other entities from outside the cluster & 0 & 1 & 2 & 2 & 0 \\
\hline Access to financing, obtaining funds & 0 & 1 & 1 & 2 & 1 \\
\hline $\begin{array}{l}\text { Participating in working on and implementing a strategy of tourism } \\
\text { development on the level of local and voivodeship authorities }\end{array}$ & 0 & 1 & 1 & 2 & 1 \\
\hline Enlargement of the product range / services in the company & 0 & 2 & 1 & 2 & 0 \\
\hline Products and tourist services sales support (marketing and promotion) & 1 & 2 & 0 & 2 & 0 \\
\hline $\begin{array}{l}\text { Implementing new technologies into the company activity on the basis of } \\
\text { knowledge / external funds associated with cluster partnership }\end{array}$ & 2 & 1 & 0 & 2 & 0 \\
\hline $\begin{array}{l}\text { Financing investments in own company on the basis of external funds (e.g. EU } \\
\text { funds) knowledge of which was a result of cluster partnership }\end{array}$ & 1 & 1 & 2 & 1 & 0 \\
\hline Access to free training courses and workshops & 0 & 2 & 1 & 1 & 1 \\
\hline
\end{tabular}

Most of experts did not notice any effect of cluster on strengthening their competitive position, developing management skills, changing the approach to innovations and cooperation, internationalization of products, promotions of employees for realizing cluster program and improving region's attractiveness by strengthening the tourism sector.

Most experts did not notice any effects or had no opinion on how cluster contributed to the recognition of the company, products and services and to the development of local initiatives. Other noticeable discrepancies among experts may result from the fact that a certain part of cluster members were more active in the cluster actions for various reasons (see Table 8).

Table 8. Evaluation of cluster activity based on modified COO estimation according to prestige criterion in experts' opinion (source: own elaboration)

\begin{tabular}{|c|c|c|c|c|c|}
\hline \multirow[b]{2}{*}{ Prestige criterion } & \multicolumn{5}{|c|}{ Level } \\
\hline & 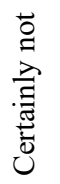 & 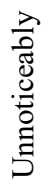 & 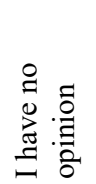 & 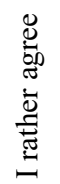 & 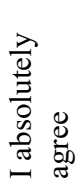 \\
\hline $\begin{array}{l}\text { Organization/participation in meetings, conferences, trade shows, foreign } \\
\text { assignments associated with the realization of the cluster program }\end{array}$ & 0 & 2 & 0 & 2 & 1 \\
\hline Strengthening of the regional tourist brand & 0 & 2 & 0 & 2 & 1 \\
\hline Trade prestige associated with cluster partnership & 0 & 2 & 0 & 2 & 1 \\
\hline $\begin{array}{l}\text { Tourist promotion of the region and cluster partners on domestic and foreign } \\
\text { market }\end{array}$ & 0 & 2 & 0 & 2 & 1 \\
\hline Incorporating tourism into the regional development strategy & 0 & 1 & 2 & 2 & 0 \\
\hline $\begin{array}{l}\text { Awareness of the importance of innovation and the impulse to the realization } \\
\text { of new projects }\end{array}$ & 0 & 2 & 1 & 2 & 0 \\
\hline Intensification of promotional activities & 1 & 2 & 0 & 2 & 0 \\
\hline
\end{tabular}


Ryszkowska, D.; Golębieska, K.; Adamiak, C.; Ostrowska-Tryzno, A.; Klawender, J.; Ryszkowski, W. 2019. Evaluation of the initiatives of the eastern Poland tourism brands cluster using a modified coo effect model

End of Table 8

\begin{tabular}{|c|c|c|c|c|c|}
\hline \multirow[b]{2}{*}{ Prestige criterion } & \multicolumn{5}{|c|}{ Level } \\
\hline & 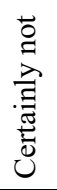 & 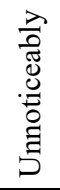 & 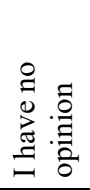 & 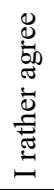 & 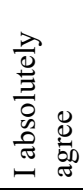 \\
\hline Strengthening the position towards competition & 0 & 3 & 0 & 2 & 0 \\
\hline Skillful management of the private brand & 0 & 3 & 0 & 2 & 0 \\
\hline $\begin{array}{l}\text { Changes in cognitive and behavioral attitude towards innovation and } \\
\text { cooperation (work process) }\end{array}$ & 0 & 3 & 0 & 1 & 1 \\
\hline Internationalization of products in own company & 0 & 3 & 1 & 1 & 0 \\
\hline $\begin{array}{l}\text { Promotions for employees associated with the implementation of the tourist } \\
\text { cluster program }\end{array}$ & 2 & 2 & 0 & 1 & 0 \\
\hline $\begin{array}{l}\text { Enhancement of innovation and attractiveness of the region through } \\
\text { strengthening the tourism sector }\end{array}$ & 0 & 3 & 0 & 1 & 1 \\
\hline Greater recognition of the company/products/services on international market & 0 & 2 & 2 & 1 & 0 \\
\hline $\begin{array}{l}\text { Increase of significance of local initiatives as the factors festinating } \\
\text { entrepreneurship, creativity and social innovations }\end{array}$ & 0 & 2 & 1 & 1 & 1 \\
\hline
\end{tabular}

\subsection{Category of modernity}

Designing new joint products/services with other institutions was definitely positively evaluated by 2 experts. However, these projects were rated as unnoticeable by one other expert and another one had no opinion on this subject. Similar assessments were noted in the case of raising funds for industry activities.

The reduction of marketing costs was noticed by two experts, while three experts experienced a negligible reduction of costs or did not feel it at all. The reduction in unemployment in the region was noticed by the minority (2), the remaining respondents had diverse opinions. Also, two respondents rather agreed that there was an increase in the number of tourists, and therefore an increase in employment and extension of tourist season, as well as modern employee monitoring. However, the other two experts rated the modern monitoring of employees negatively. Also, in the opinion of two experts, the cooperation between cluster members and the administration was insignificant.

Table 9. Evaluation of cluster activity based on modified COO estimation according to modernity criterion in experts' opinion (source: own elaboration)

\begin{tabular}{|c|c|c|c|c|c|}
\hline \multirow[b]{2}{*}{ Prestige criterion } & \multicolumn{5}{|c|}{ Level } \\
\hline & 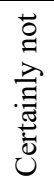 & 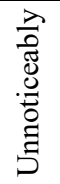 & 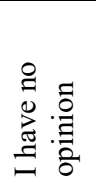 & 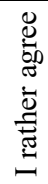 & $\begin{array}{l}\frac{\lambda}{0} \\
\stackrel{0}{0} \\
0 \\
0 \\
0 \\
0 \\
0 \\
0\end{array}$ \\
\hline Designing new products/services shared with other institutions & 0 & 2 & 1 & 0 & 2 \\
\hline Obtaining funds on the activity in tourism and hotel trade & 1 & 1 & 1 & 0 & 2 \\
\hline Reducing the costs e.g. marketing and more efficient promotion of the region & 1 & 2 & 0 & 2 & 0 \\
\hline Decreasing unemployment in the nearest region & 1 & 1 & 1 & 2 & 0 \\
\hline Increase of the number of tourists/clients and revenue & 0 & 2 & 1 & 2 & 0 \\
\hline $\begin{array}{l}\text { Employment growth in broadly defined tourism in the region and prolongation } \\
\text { of the tourist season }\end{array}$ & 0 & 2 & 1 & 2 & 0 \\
\hline Innovation and competitiveness growth & 1 & 1 & 2 & 0 & 1 \\
\hline Modern monitoring and evaluation of employees & 2 & 1 & 0 & 2 & 0 \\
\hline $\begin{array}{l}\text { Facilitation of cooperation between cluster partners and administrative } \\
\text { institutions }\end{array}$ & 0 & 2 & 1 & 1 & 1 \\
\hline Reducing costs of activity in a cluster member company & 2 & 1 & 1 & 1 & 0 \\
\hline Modernization of infrastructure in own company & 2 & 1 & 1 & 1 & 0 \\
\hline Introducing tangible innovations in a company & 2 & 1 & 1 & 1 & 0 \\
\hline Usage of professional consulting in the company's activity & 0 & 2 & 1 & 1 & 1 \\
\hline
\end{tabular}


Two experts assessed definitely negatively the reduction of operating costs, modernizing the infrastructure and introducing innovations in the company. Large discrepancies were noticed in the assessment of using professional advice in the company operations. Unnoticeable changes and lack of opinion were indicated by 3 experts, and the acknowledgement of positive effects of professional consultancy was declared by two experts (see Table 9).

\subsection{Overall evaluation of activity and initiatives in the Eastern Poland Tourist Brands Cluster}

Experts' opinions show that the quality criterion was most highly rated, which would suggest that cluster membership allowed improving contacts with the competitors, developed a more thoughtful approach to them and, to a lesser extent, increased product and service quality. Participation in the cluster project allowed expanding and diversifying tourist offer. Prestige related to cluster membership was not so significant, but noticeable. Modernity of services, products and solutions was found the least important. Experts evaluations on the modernity effects associated with cluster activity were quite negative.

Final results demonstrate that retrospectively a similar number of experts evaluated cluster activities as unnoticeable (33.29\%) and as rather congruent with certain cluster objectives (31.99\%). 16.59\% of experts could not express their opinion on the cluster activity, which suggests that some cluster members were involved only in some activities, or were not involved in cluster initiatives at all (see Table 10).

Table 10. Evaluation of cluster activity based on modified COO model according to all the criteria in experts' opinion (source: own elaboration)

\begin{tabular}{|c|c|c|c|c|c|c|c|c|c|c|}
\hline \multirow{3}{*}{$\begin{array}{l}\text { Quality criterion } \\
\text { Quality }\end{array}$} & \multicolumn{10}{|c|}{ Level } \\
\hline & \multicolumn{2}{|c|}{ Definitely not } & \multicolumn{2}{|c|}{ Unnoticeable } & \multicolumn{2}{|c|}{ I have no opinion } & \multicolumn{2}{|c|}{ I rather agree } & \multicolumn{2}{|c|}{ I definitely agree } \\
\hline & 0.00 & $0.00 \%$ & 1.71 & $34.29 \%$ & 1.00 & $20.00 \%$ & 2.00 & $40.00 \%$ & 0.43 & $8.57 \%$ \\
\hline Diversity & 0.29 & $5.71 \%$ & 1.21 & $24.29 \%$ & 0.93 & $18.57 \%$ & 1.64 & $32.86 \%$ & 0.93 & $18.57 \%$ \\
\hline Prestige & 0.20 & $4.00 \%$ & 2.27 & $45.33 \%$ & 0.47 & $9.33 \%$ & 1.60 & $32.00 \%$ & 0.47 & $9.33 \%$ \\
\hline Modernity & 0.92 & $18.46 \%$ & 1.46 & $29.23 \%$ & 0.92 & $18.46 \%$ & 1.15 & $23.08 \%$ & 0.54 & $10.77 \%$ \\
\hline Average in total & 0.35 & $7.04 \%$ & 1.66 & $33.29 \%$ & 0.83 & $16.59 \%$ & 1.60 & $31.99 \%$ & 0.59 & $11.81 \%$ \\
\hline
\end{tabular}

\section{Discussion and conclusions}

Various research methods and techniques were used to analyze cluster initiatives. The assessments are often done in accordance with the assumptions of the projects financing the clusters. Ratings are usually based on the use of financial resources for specific purposes. The general and often fragmentary assessments (Hopeniene \& Rutelione, 2016) use current data on cluster initiatives (reports, descriptions, in-depth observations of cluster development) (RosińskaBukowska, 2012). Many authors used the Porter Model. To assess the differences between tourist cluster activities, comparative methods (statistical and expert) are employed: opinions of various groups, statistical clustering methods, measurements of the degree of connection, importance of links, discriminatory models and methods of classification of entities. Some authors assess cluster performance with the use of multimethodology, which includes the assessment of respondents and the descriptive assessment of cluster initiatives (Cardoso, Themido, \& Moura Pires, 1999). Other authors, in reference to the European Cluster Observatory proposal (Sölvell, 2008), used information about companies for cluster assessment (geographical data, region identification, turnover, classification of economic activity, cluster analysis of entities). The above studies were based on the use of secondary data and the use of quantitative multidimensional analysis. These methods of research were aimed at indicating the competitiveness of tourism clusters, the level of regional development and determining the region competitiveness (Estevão \& Ferreira, 2012). Yet other researchers used a method based on a semi-structural in-depth interview and qualitative research on the level of tourism cluster development, and various dimensions of relationship quality: trust, satisfaction, openness to communication, certainty, commitment, investments, behavioural intentions, determinants of cluster dynamics (Hopeniene \& Rutelione, 2016). In the present research, descriptive analysis was used together with the modified assumptions of the $\mathrm{COO}$ model and other cluster models. This solution allowed the cluster to be evaluated on the basis of source materials and versatile expert assessment. Co-authors of the present article already used the assumptions of the COO model in the assessment of modern solutions in tourism in rural areas (Kozłowska, Ryszkowski, \& Vasilchenko, 2016).

The analysis showed that with the end of financing the cluster project, the activity of its members dropped drastically, which is confirmed by experts, an interview with an PSDiK employee and entries on the cluster's website. Common cluster initiatives have developed a small number of tourist package products addressed to customers. Typically, packages were offered by members who acted together already before joining the cluster, e.g. they were a hotel group. Packages and products of cluster members presented in cluster news were previously offered by the same companies under the same or different names, eg. St. Andrew's Day, New Year's Ball, Valentine Day, etc. A common and innovative networking product offered in the cluster was the Baśniowa Trail in the Suwałki Region. Still, this 
product was previously implemented by the cluster within the project promoting the region "Suwałki Region as a fairy tale". No specific and original solutions of offered services and products were noticed. Research confirms that the main benefits of membership in the cluster were related to establishing inter-institutional cooperation and promotional campaigns of the region during trade missions and fairs. The significance of cooperation is confirmed by government document. According to the Polish Marketing Strategy in the Tourism Sector 2012-2020 (Walas, 2008), the dialogue of partners is necessary for the development of Polish tourism (Wilk-Grzywna, 2015).

Research has shown that more than half of cluster members' activities were related to the offer of tourist packages, while much less activities were associated with workshops, fairs and other events, as well as with participation in competitions and conferences related to the implementation of the project and other training, conferences and seminars. Occasionally, sports events, meetings with interesting people, participation in fairs and more have appeared.

The best effects of the region's promotion and the development of cluster members' products and services were obtained thanks to participation in many cluster events: program and project meetings, training conferences, economic missions. It allowed to increase promotional activities in the country and abroad (USA, Russia, Belarus and others). It also enabled cluster members to gain knowledge and skills of cooperation, and successfully apply for funds for development. It improved and facilitated contacts between institutions selling similar products, establishing interinstitutional links. It helped to acquire practical knowledge about tourism innovations, and increase the awareness of the sales of own products among cluster members. Also, it allowed the acquisition of new customers and acquiring the ability to reflect on innovation and modernity. The above is confirmed by other studies (Klemens, 2016, 50). In expert opinions, the cluster activities and initiatives were rated higher in the criterion of quality, diversity and prestige than in relation to modernity. Due to its traditional character, tourism industry has a low level of innovation and lower level of specialist skills required in relation to industrial sectors (Bembenek, 2015). It would be better, therefore, to emphasize the role of academic members of tourist clusters so that they focus their activities more on improving tourism products.

The cluster initiatives have not definitely contributed to the development of tourism services and products. It was admitted that better information about products and services was noticeable. Individuals pointed to the internationalization of products and their greater recognition. The experts had divided opinions related to the expansion of the array of products and services offered, the design of new joint products and services, as well as modern monitoring and assessment of employees. The strength of the tourist brand of the region and marketing products/services have not been undoubtedly improved by cluster activities, which is contrary to other studies on tourist clusters (Borkowska-Niszczota, 2015b, p. 160).

It is possible that a better selection of cluster members among truly active, innovative and product-focused entrepreneurs could contribute to more dynamic operation and prolonging the cluster activities. Local and regional authorities should also be more interested in promoting the region and products, which would translate into profits in other industries. Their greater involvement would significantly contribute to the cluster activity, which is supported by the research on the activities of another tourist cluster "Land flowing with milk and honey", which achieved success despite difficult beginnings and maintained its activity after the end of financing. The basis for success was the cooperation with organizations that had many years of experience in the industry (chambers of commerce, local tourist organizations). These studies also showed that the cluster initiative should be created together by regional and cooperating companies, research and development sector institutions and local government authorities (Duczmala \& Potwor, 2010, pp. 49-50). The analysis of clusters activities in Poland showed cluster members had little expectations regarding cooperation with local authorities (Bembenek, 2015). Other studies, in turn, have shown that there is a connection between the quality of cooperation and links between cluster members, and the dynamics of tourist clusters (Hopeniene \& Rutelione, 2016, p. 245).

In fact, the objectives of the cluster set in the project have been achieved, but their effectiveness could be much higher taking into account the resources. Cluster organization would have a better chance of survival then. This would make the region more competitive and recognizable. Establishment of clusters should include organizations and entrepreneurs who could establish actual partnerships, support each other and introduce new common products. Therefore, also before the establishment of a cluster, research is needed on the objectives of establishing interinstitutional ties, which was missing in case of the analyzed cluster. Lack of precise guidelines for cooperation, a fragmentary description of the relationship and the attribution of responsibility among cluster members largely contributes to its disintegration. The decisions of establishing clusters should be based on constructive and reliable research conducted among correctly selected samples and the analysis of types and possibilities of establishing the inter-institutional relations between entrepreneurs - potential cluster participants. This would help to avoid eventual decay of cluster initiatives in the tourism industry.

\section{Acknowledgements}

We would like to thank the experts who participated in the research related to this publication and an employee of the Polish Advisory and Consulting Association for providing materials and granting basic information related to the Eastern Poland Tourist Brands Cluster. 
Ryszkowska, D.; Gotębieska, K.; Adamiak, C.; Ostrowska-Tryzno, A.; Klawender, J.; Ryszkowski, W. 2019. Evaluation of the initiatives of the eastern Poland tourism brands cluster using a modified coo effect model

\section{References}

Alberti, F. G., \& Giusti, J. D. (2012). Cultural heritage, tourism and regional competitiveness: The Motor Valley cluster. City, Culture and Society, 3(4), 261-273. https://doi.org/10.1016/j.ccs.2012.11.003

Arsezen-Otamisa, P., \& Yuzbasioglu, N. (2013). Analysis of Antalya tourism cluster perceived performance with structural equation model. Procedia-Social and Behavioral Sciences, 99, 682-690. https://doi.org/10.1016/j.sbspro.2013.10.539

Bembenek, B. (2015). Membership satisfaction and in managing cluster development. Zeszyty Naukowe Uniwersytetu Szczecińskiego No 867. Problemy zarządzania, finansów i marketingu, 40, 239-255. https://doi.org/10.18276/pzfm.2015.40-20

Boguszewicz-Kreft, M., Magier-Łakomy, E., \& Janiunaite, B. (2016, 27 April). Dimension of the country of origin effect in the perception of medical services in EU countries- an international comparison. 23 ${ }^{\text {rd }}$ International Academic Conference (pp. 306-317). Venice. https://doi.org/10.20472/IAC.2016.023.065

Boguszewicz-Kreft, M., \& Magier-Łakomy, E. (2016). The image of products and services from highly developed European countries-the multidimensionality of the country-of-origin effect. Studia Ekonomiczne. Zeszyty Naukowe, 254, 19-29.

Boguszewicz-Kreft, M., Magier-Łakomy, E., Sokołowska, K., \& Janiunaite, B. (2016). Dimensions of the COO Effect referring to services and products - Polish Lithuanian comparisons. $3^{\text {rd }}$ Business \& Management Conference (pp.48-64). Lisbon. https://doi.org/10.20472/BMC.2016.003.006

Boguszewicz-Kreft, M. (2014). Country image effects in education services. Marketing iRynek, 8, 332-337.

Borkowska-Niszczota, M. (2015a). Tourism clusters in Eastern Poland - analysis of selected aspects of the operation. International Scientific Conference Economics and Management-2015 (ICEM-2015). Procedia-Social and Behavioral Sciences, 213, 957964. https://doi.org/10.1016/j.sbspro.2015.11.511

Borkowska-Niszczota, M. (2015b). The impact of tourism clusters on the development and competitiveness of regions. Economic Problems of Tourism, 2(30), 145-164. https://doi.org/10.18276/ept.2015.2.30-09

Capone, F. (2004). Regional competitiveness in tourism local systems. 44th European Congress of the European Regional Science Association, Regions and Fiscal Federalism. Universidad the Porto: Portugal.

Cardoso, M. G. M. S., Themido, I. H., \& Moura Pires, F. (1999). Evaluating a clustering solution: An application in the tourism market. Intelligent Data Analysis, 3, 491-510. https://doi.org/10.3233 / IDA-1999-4606

Cristea, A., Capatina, G., \& Stoenescu, R. D. (2015, 30-31 October). Country-of-origin effects on perceived brand positioning. $2^{\text {nd }}$ Global Conference on business, economics, management and tourism. Prague, Czech Republic, 2014. Procedia Economics and Finance, 23, 422-427. https://doi.org/10.1016/S2212-5671(15)00383-4

Del Chiappa, G., Atzeni, M., \& Ghasemi, V. (2018). Community-based collaborative tourism planning in islands: A cluster analysis in the context of Costa Smeralda. Journal of Destination Marketing \& Management, 8, 41-48. https://doi.org/10.1016/j.jdmm.2016.10.005

Dinnie, K. (2004). Country-of-origin 1965-2004: A literature review. Journal of CustomerBehavior, 3(2), $165-213$. https://doi.org/10.1362/1475392041829537

Duczmala, W., \& Potwor, W. (2010). Klastry i inicjatywy klastrowe w województwie opolskim. Tom 1. Wydawnictwo Instytut Śląski, Opole, Poland.

Dzierżanowski, M. (Ed.). (2012). Kierunki i założenia polityki klastrowej w Polsce do 2020 roku. Rekomendacje grupy roboczej ds. polityki klastrowej. Warsaw, Poland. Polska Agencja Rozwoju Przedsiębiorczości.

Estevão, C. M. S., \& Ferreira, J. (2009). The tourism clusters role in regional development: presenting a competitiveness conceptual model. Tourism Destination Development and Branding, 127-139. Retrieved from https://repositorio.ipcb.pt/bitstream/10400.11/1479/1/tourism.pdf

Estevão, C. M., \& Matos Ferrieira, J. J. (2012). Tourism cluster positioning and performance evaluation: The case of Portugal. Tourism Economics, 18(4), 711-730. https://doi.org/10.5367/te.2012.0137

Fundeanu, D. D. (2015, 30-31 October). The tourism clusters role in regional development: presenting a competitiveness conceptual model. $2^{\text {nd }}$ Global Conference on Business, Economics, Management and Tourism. Procedia Economics and Finance, 23, 744-749. Prague, Czech Republic. https://doi.org/10.1016/S2212-5671(15)00501-8

García-Villaverde, P. M., Elche, D., Martínez-Pérez, Á., \& Ruiz-Ortega, M. J. (2017). Determinants of radical innovation in clustered firms of the hospitality and tourism industry. International Journal of Hospitality Management, 61, 45-58. https://doi.org/10.1016/j.ijhm.2016.11.002

Gardiner, S., \& Scott, N. (2014). Successful tourism clusters: Passion in paradise. Annals of Tourism Research, 46, 171-173. https://doi.org/10.1016/j.annals.2014.01.004

Gorynia, M., \& Jankowska, B. (2010). Clusters as the basis for creating areas of high productivity. In A. Grzelak \& K. Pajak (Eds.), Nowe trendy w metodologii nauk ekonomicznych. Tom I. Problemy ogólne nauk ekonomicznych (pp. 101-121). Poznan, Poland, Wydawnictwo Uniwersytetu Ekonomicznego.

Hoffmann, R. (2000). Country of origin - a consumer perception perspective of fresh meat. British Food Journal, 102(3), $211-229$. https://doi.org/10.1108/00070700010332304

Hopeniene, R., \& Rutelione, A. (2016). Relationship quality in tourism: A Case of local tourism cluster in Lithuania. Lex LocalisJournal of Local Self-Government, 14(2), 225-249. https://doi.org/10.4335/14.2.225-249

Jackson, J., \& Murphy, P. (2006). Clusters in regional tourism: An Australian case. Annals of Tourism Research, 33(4), 1018-1035. https://doi.org/10.1016/j.annals.2006.04.005 
Ryszkowska, D.; Gotębieska, K.; Adamiak, C.; Ostrowska-Tryzno, A.; Klawender, J.; Ryszkowski, W. 2019. Evaluation of the initiatives of the eastern Poland tourism brands cluster using a modified coo effect model

Jaworski, J. P., Boguszewicz-Kreft, M., \& Magier-Lakomy, E. (2015). Country of origin effect in the perception of banking services in Poland. Pilot Studies. Annales Universitatis Mariae Curie-Skłodowska. Sectio H, Oeconomia, 49(4), 169-176. https://doi.org/10.17951/h.2015.49.4.169

Jung, S. S., \& Jang, S. S. (2018). To cluster or not to cluster?: Understanding geographic clustering by restaurant segment. International Journal of Hospitality Management, 77, 448-457. https://doi.org/10.1016/j.ijhm.2018.08.008

Kachniewska, M. (2013). Towards the definition of a tourism cluster. Journal of Entrepreneurship Management and Innovation (JEMI), 9(1), 33-56.https://doi.org/10.7341/2013913

Klasterturystyczny.pl. (2019). Klaster Marek Turystycznych Polski Wschodniej. Retrieved from http://www.klasterturystyczny.pl

Klemens, B. (2016). Tourism initiatives and clusters and their influence on regional development. In B. Solga (Ed.), Przeglad nauk stosowanych, 12, 41-53). Opole, Poland: Politechnika Opolska.

Kozłowska, D., Ryszkowski, W., \& Vasilchenko, A. (2016). Modern solutions in selected tourist facilities in rural areas of NorthEastern Poland. In M. Biczkowski \& R. Rudnicki. (Eds.), Socio-economic dimension of innovations in rural areas (pp. 171184). Warsaw, Poland: Polish Academy of Sciences.

Laing, C., \& Lewis, A. (2017). Exploring clustering as a destination development strategy for rural communities: The case of La Brea, Trinidad. Journal of Destination Marketing \& Management, 6(3), 184-195. https://doi.org/10.1016/j.jdmm.2016.03.006

Martínez-Pérez, A., García-Villaverde, P., \& Elche, D. (2016). The mediating effect of ambidextrous knowledge strategy between social capital and innovation of cultural tourism clusters firms. International Journal of Contemporary Hospitality Management, 28(7), 1484-1507. https://doi.org/10.1108/IJCHM-08-2014-0405

McLennan, C. J., Becken, S., \& Watt, M. (2016). Learning through a cluster approach: lessons from the implementation of six Australian tourism business sustainability programs. Journal of Cleaner Production, 111, 348-357. https://doi.org/10.1016/j.jclepro.2015.01.085

Novelli, M., Schmitz, B., \& Spencer, T. (2006). Networks, clusters and innovation in tourism: A UK experience. Tourism Management, 27(6), 1141-1152. https://doi.org/10.1016/j.tourman.2005.11.011

Polskie Stowarzyszenie Doradcze i Konsultingowe. (2013). Klaster Marek Turystycznych Polski Wschodniej. Podlaskie Targi Turystyczne 2013. Retrieved from http://www.bialystokonline.pl/psdik-klaster-marek-turystycznych-polski-wschodniej,targi,1,3,15.html

Porter, M. (1990). The competitive advantage of nations. New York, US: Free Press. https://doi.org/10.1007/978-1-349-11336-1

Porter, M. (2002). Regional foundations of competitiveness and implications for government policy. Paper presented to Department of Trade and Industry Workshop, April.

Rosińska-Bukowska, M. (2012). Clustering as an element of regional development policy (evaluation of cluster initiatives selected Łódź region). ActaUniversitatisLodziensis. Folia Geographica Socio-Oeconomica, 12, 55-80.

Roth, M. S., \& Romeo, J. B. (1992). Matching product category and country image perceptions: A framework for managing countryof-origin effects. Journal of International Business Studies, 23(3), 477-497. https://doi.org/10.1057/palgrave.jibs.8490276.

Skowronek, E. (2015). Cluster as a form cooperation in tourism. Europa Regionum, 24, 129-140. https://doi.org/10.18276/er.2015.24-12

Sölvell, Ö. (2008, 17-18 September). Methodologies and indicators for analyzing and benchmarking cluster-specific framework conditions. European Cluster Observatory, Expert Workshop, Copenhagen.

Walas, B. (2008). Polish marketing strategy in the tourism sector 2012-2020. Retrieved from https://www.pot.gov.pl/pl/opot/plany-i-sprawozdania-pot/marketingowa-strategia-polski-w-sektorze-turystyki-na-lata-2012-2020-2

Wilk-Grzywna, M. (2015). The concept of tourism products' clustering. Case Study: Tropical North Queensland in Australia and Green Velo Eastern Cycle Trail in Poland (pp. 169-183). Studia KPZK,162. 